技術報告

\title{
にがりを用いた応染料及ひ食用タール系色素廃水の 沈殿除去処理
}

関洋 子*·濱田(佐藤) 奈 保 子*

\section{要旨}

水質保全のためには廃水を適切に処理する必要があり, このうち着色水の処理には凝集沈殿法が有効と言 われている，現在数多くの凝集剤があるが，本報では，凝集剂としてにがりを利用した着色水の処理法を提 案する。にがりとは製塩の際に生成される副産物で $\mathrm{Mg}$ を多く含む液体である。にがりは製塩法の違いによ り海水濃縮にがりとイオン交換膜濃縮にがりの 2 種類があり, 海水濃縮にがりは $\mathrm{Mg}$ 及び $\mathrm{SO}_{4}$ を多く含み, イオン交換膜濃縮にがりは $\mathrm{Mg}$ 及び $\mathrm{Ca}$ を多く含むという特徵がある。幅広く染色に利用されている反応染 料及び食用タール系色素溶液をこれらのにがりで沈殿除去し，にがりの種類による効果の比較検討を行った ところ, イオン交換膜濃縮にがりが高い効果を示し, 有効であることを明らかとした。 イオン交換膜濃縮に がり中の $\mathrm{Mg}$ と $\mathrm{Ca}$ は $\mathrm{pH}$ 上昇に伴い，それぞれ $\mathrm{Mg}(\mathrm{OH})_{2}, \mathrm{CaCO}_{3}$ となり沈殿するが，これらに着色成分が 取り込まれている可能性が高いことをX線回折分析により考察した.

キーワード：にがり, 反応染料, 食用タール系色素, 沈殿除去

\section{1. 緒 言}

染色, 染料製造工場等, 染料を扱う工場から出る廃 水は染料が混入し着色していることが多い.このよう な廃水は，廃水中に含まれる污濁物質を除去する処理 が施されるが，染料等着色成分を完全に除去すること は難しい，人間は色に対して敏感であるので, ごく微 量の場合でも不快な印象を受ける1．

現在工場から排出される着色水は各地方自治体の条 例でその基準が定められている。このため工場内で着 色廃水の処理が必要であり, 物理化学的処理・生物的 処理を組み合わせた処理が行われている。代表的な物 理化学的処理としてはオゾン処理, 紫外線照射, 活性 炭処理, 凝集沈殿処理があり, 生物的処理では生物の 機能を用いた分解が挙げられる。着色廃水では原因物 質は大きい粒子であることが多く, 凝集沈殿で除去で きる可能性が高い.
凝集沈殿とは水中の微粒子をまとめて大きな塊とし て沈殿させる方法であり，代表的な凝集剤は無機凝集 剤としてミョウバン，塩化第二鉄などで，アルミニウ ムや鉄といった金属イオンの凝集作用を利用してお り，高分子凝集剂としてアニオンポリマー，ノニオン ポリマーといった分子の架橋作用を利用したものがあ る。現在これらの凝集剤は化学合成あるいは精製され て製造されており，無機凝集剂は20円 / kg程度，高分 子凝集剤は 800 円 $/ \mathrm{kg}$ 程度である ${ }^{2)}$.

金属イオンを多く含む液体としてにがりがある。に がりは製塩の副産物で，塩化マグネシウムを主成分と する液体である，製塩の副産物であるため海水の水温 や塩分濃度など季節や天候に左右され，成分が一定し ないため,メーカーは成分を基準範囲内になるように 加工して出荷している。この加工にコストがかかるた め, 現在にがりは末端価格で130円 / kg程度での販売 となっている，加工前のにがりの $\mathrm{Mg}$ 濃度は約0.5
Removal of Reactive Dyes and Food Coal-tar Dyes from Wastewater by Precipitation with Bitterns

*東京海洋大学大学院海洋科学技術研究科 Hiroko SEKI, Naoko HAMADA-SATO
2011年12月22日受付 2012年 4 月 10 日受理 
$5 \%$ と濃度にばらつきはあるが3), 加工しなくても凝 集剂としては十分利用可能である，現在国内で生産さ れたにがりは化成品や豆腐の凝固剤として利用されて いるが，一部は廃棄されている。海外では2006〜2007 年にかけてカリフォルニア州レッドウッド・シティで 穀物大手のカーギル社がにがり654,000 L を海に廃棄 している ${ }^{4)}$.にがりは製塩法の違いにより, 海水濃縮 にがりとイオン交換膜濃縮にがりに分けられる。どち らも主成分は塩化マグネシウムであるが，海水濃縮に がりはCaが少なく, $\mathrm{SO}_{4}$ が多いという特徵があり，

イオン交換膜濃縮にがりは Ca が多く, $\mathrm{SO}_{4}$ が少ない という特徴がある ${ }^{5)}$ ．マグネシウムを含む溶液にアル カリ溶液を添加して高 $\mathrm{pH}$ 域にすると水酸化マグネシ ウムのゲル状の沈殿を生じる。その沈殿物内に着色物 質は取り込まれ (共沈), 除去されると推定される.

にがりを用いた着色廃水の沈殿除去に扮ける試みと しては, 特定の染料工場廃水の処理を海水濃縮にがり で行った例が報告されている ${ }^{6)}$. 同報告の着色物質と しては，同工場で使用された染料を対象としており， 着色物質の種類等の詳細な情報はなく, にがりの種類 による除去効果の比較は行われていない.

着色物質は多くの種類があるが, 本報では染料の構 造が明らかになっている反応染料と食用タール系色素 を対象とした，反応染料は木綿やレーヨンを染めるの にもっとも多く利用されている染料であり, 多くの種 類が開発されている。食用タール系色素は厚生労働省 の指定添加物であり, 工業製品の着色料, 医薬品, 化粧 品, 食品添加物に使用されている. 日本では食品や医薬 品を着色する場合は安全性の確立した使用が認可され ている色素は少数のため, これらの色素を混合して色 を調整することが多く,幅広い染色に使用されている.

本報では，反応染料及び食用タール系色素を種類の 異なるにがり（海水濃縮にがりとイオン交換膜濃縮に がり）で除去処理し，にがりの種類による効果の比較 検討を行うことを目的とした．また，にがり中に含ま れる成分を測定することにより, $\mathrm{Mg}$ 以外のにがりの 成分が沈殿除去に与える影響を調査し, 沈殿物の結晶 構造の確認をX線回折分析により評価し，にがりの凝 集剂としての役割を検証した。

\section{2. 実験方法}

\section{1 試 料}

反応染料は Reactive Black 5 (ICN Biomedical),
Reactive Orange 14, Reactive Blue 5, Reactive Blue 19 （SIGMA）を用いた。食用タール系色素はFood Red No.2, Food Red No.40, Food Red No.3, Food Red No.106(東京化成侏)を用いた(表 1 ; 次頁).にが りは,「塩焚き爺の天然にがり」(ユリヤ製塩所)，「石垣島 天然本にがり」(石垣の塩),「室戸海洋深層水天然にが り」(室戸海洋深層水),「瀬讃のにがり」(日本海水)の 4 種を用いた。試薬は塩化マグネシウム 6 水和物（国産 化学(侏), 特級), 塩化カルシウム 2 水和物 (国産化学(侏), 特級), 硫酸ナトリウム (和光純薬(侏), 特級), 炭酸力 ルシウム (国産化学(侏), 1 級), 水酸化カルシウム (国 産化学(侏), 1 級), 水酸化マグネシウム (和光純薬(株) を用いた. $\mathrm{pH}$ 調整は水酸化ナトリウム(和光純薬(侏), 特級）を用いた。

\subsection{1 にがりの $\mathrm{Ca}, \mathrm{Mg}, \mathrm{SO}_{4}$ 成分の測定}

にがり約 $8 \mathrm{~mL}$ を正確にはかりとり，500mLのメス フラスコに移し入れ定容し, 検液とした ${ }^{7)}$ 。これを 4 〜100倍に希釈し ICP-AES（セイコーインスッルメン ッ株，SPS7800）で各成分の濃度を測定した。測定は 標準添加法で行った。濃度は以下の式より算出した。

$$
\begin{aligned}
& \text { イオン濃度 }(\%)= \\
& \frac{\mathrm{ICP} \text { 測定結果 }(g / L) \times \text { 希釈倍率 } \times \mathrm{f}}{\text { にがり量 }(g)} \times 100
\end{aligned}
$$

$\mathrm{f} ：$ 各標準溶液のファクター

にがりの主成分を ICP-AES で測定した結果，塩焚き 爺の天然にがりと石垣島天然本にがりは $\mathrm{SO}_{4}$ 濃度が3.4 ～3.5\% と高く, Ca 濃度は0.015～0.018\% と低く, 海水 濃縮にがりの特徵を示した。一方, 室戸深層水天然に がりと瀬讃のにがりは Ca 濃度が1.3〜2.5\% と高く, SO4濃度は0.011 0.070\%と低く，イオン交換膜濃縮に がりの特徴を示した（表 $2 ; 51$ 頁)。以降，塩焚き爺 の天然にがりと石垣島天然本にがりを海水濃縮にがり に，瀬讃のにがりと室戸海洋深層水天然にがりをイオ ン交換膜濃縮にがりに分類した。 なお， $\mathrm{Mg}$ は海水濃 縮にがりが3.0 3.2\%，イオン交換膜濃縮にがりが4.1 〜 $5.1 \%$ で, イオン交換膜濃縮にがりは海水濃縮にが りの $\mathrm{Mg}$ 量の約1.5倍であった。

\section{2 測 定 条 件}

分光光度計による測定は波長360～760 nm のスペク トルを測定した（日本分光(株，V-630)。濃度は表 1 に記載の波長における吸光度から求めた検量線法によ り求めた。除去率は次式から算出した。 
表 1 染料の化学構造と使用波長

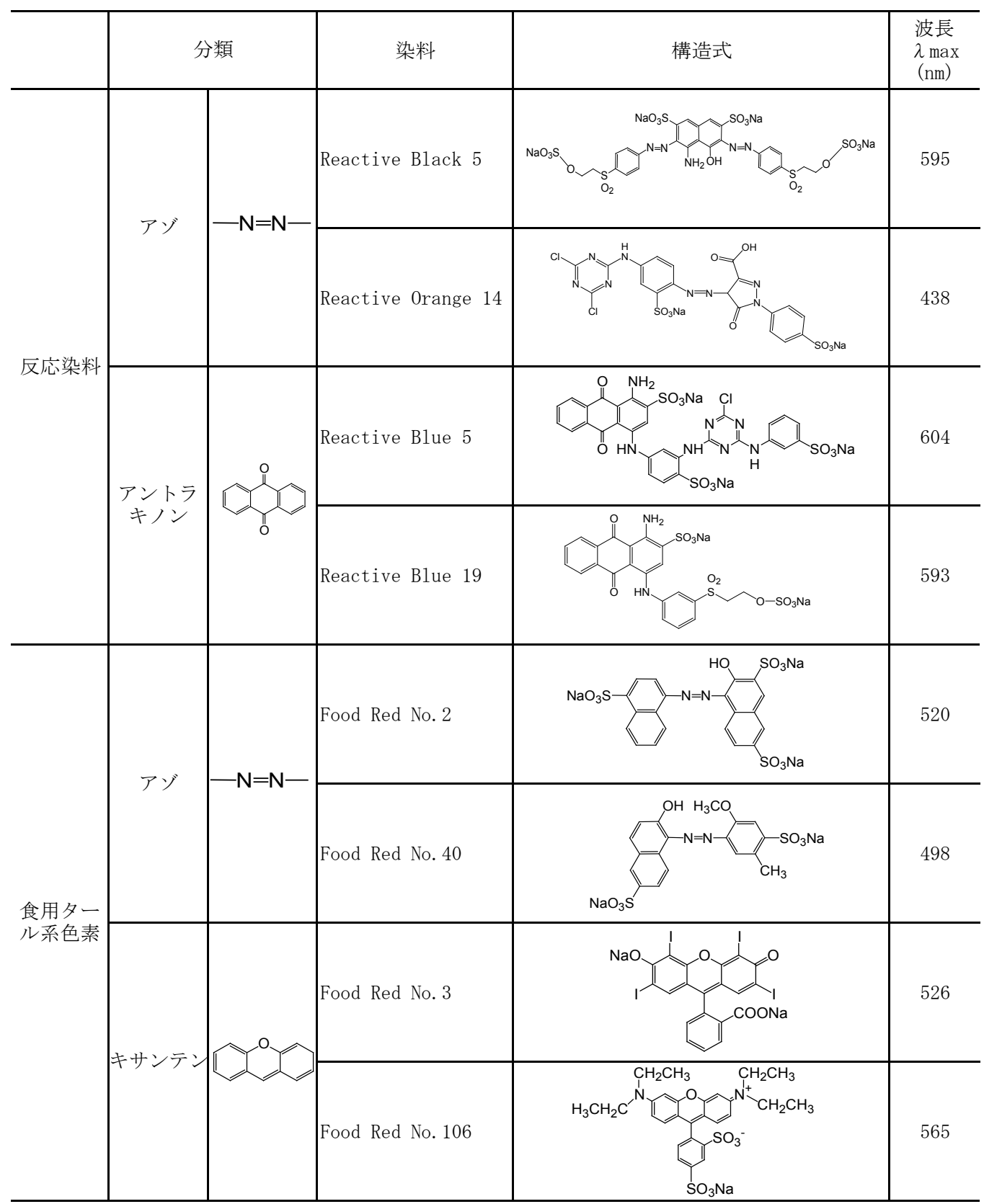

除去率 $(\%)=$

$\frac{\text { 除去後の濃度 }(\mathrm{mg} / \mathrm{L})}{\text { 初期濃度 }(400 \mathrm{mg} / \mathrm{L} \text { または } 100 \mathrm{mg} / \mathrm{L})} \times 100$

\section{3 試料溶液の調製及び測定}

\subsection{1 試料前処理条件の検討}

Reactive Blue $5400 \mathrm{mg} / \mathrm{L}$ 溶液 $50 \mathrm{~mL}$ に 4 種類の

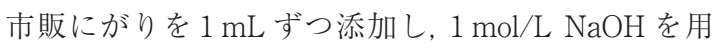
いて pH を12〜13に調整した. その後, 静置沈降の上澄 （2）みとそれをろ過した溶液をそれぞれ中和したものを試 料溶液とし, 2.2に記載の方法により除去率を算出した.

\subsection{2 反応染料または食用タール系色素の沈殿除 去処理}

反応染料 $400 \mathrm{mg} / \mathrm{L}$ 溶液 $50 \mathrm{~mL}$ と食用タール系色素 
表 2 にがり主成分の分析結果

(\%)

\begin{tabular}{llll}
\hline 商品名 & $\mathrm{Ca}$ & $\mathrm{Mg}$ & $\mathrm{SO}_{4}$ \\
\hline 塩焚き爺の天然にがり & 0.018 & 3.0 & 3.5 \\
\hline 石垣島天然本にがり & 0.015 & 3.2 & 3.4 \\
\hline 室戸海洋深層水天然にがり & 1.3 & 4.1 & 0.070 \\
\hline 瀬讃のにがり & 2.5 & 5.1 & 0.011 \\
\hline
\end{tabular}

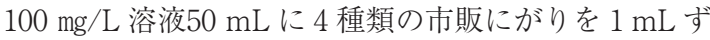
つ添加し， $1 \mathrm{~mol} / \mathrm{L} \mathrm{NaOH}$ を用いて $\mathrm{pH}$ を 12〜13に調 整した。食用タール系色素は $400 \mathrm{mg} / \mathrm{L}$ では差が確認 しにくかったため，初期濃度を比較可能な濃度である $100 \mathrm{mg} / \mathrm{L}$ に調整した。 その後，5Cのろ紙で沈殿を ろ過・除去したろ液を中和したものを試料溶液とし, 2.2に記載の方法により除去率を算出した。

\subsection{3 にがりの成分の違いが沈殿除去処理に及ぼ す影響}

Reactive Blue 5 の400 mg/L 溶液 $50 \mathrm{~mL}$ に $\mathrm{MgCl}_{2}$ $10 \%$ 溶液を $1 \mathrm{~mL}$ ずつ加え, 一方に Ca イオン $0.5 \%$ 溶 液 1〜 $5 \mathrm{~mL}$ を段階的に添加し, 他方に $\mathrm{SO}_{4}$ イオン $0.5 \%$ 溶液 $1 〜 5 \mathrm{~mL}$ を段階的に添加した。その溶液を 1 $\mathrm{mol} / \mathrm{L} \mathrm{NaOH}$ で $\mathrm{pH}$ を12〜13に調整し， $5 \mathrm{C}$ のろ紙で 沈殿を除去したろ液を中和したものを試料溶液とし, 2.2に記載の方法により除去率を算出した。

\subsection{4 にがりをアルカリ性にした際に生じる沈殿 の同定}

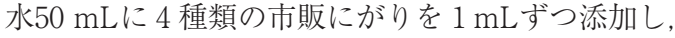
$1 \mathrm{~mol} / \mathrm{L} \mathrm{NaOH}$ を用いて $\mathrm{pH}$ を 12〜13に調整した。生 じた沈殿を乾燥させ, 乳棒・乳鉢で粉砕したものを試 料とした。この試料をX 線回折分析装置（Rigaku 製 MiniFlex II）にて $4^{\circ} \sim 90^{\circ}$ のプロファイルを測定 した。同時に $\mathrm{Mg}(\mathrm{OH})_{2}, \mathrm{CaCO}_{3}, \mathrm{Ca}(\mathrm{OH})_{2}$ の試薬に

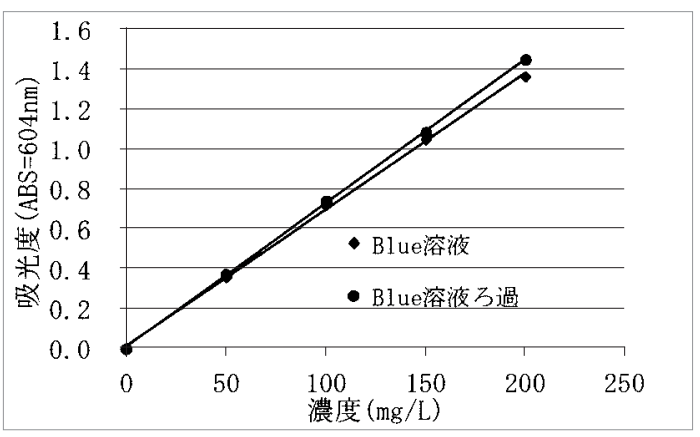

(1) Reactive Blue 5 のろ紙吸着の検討
表 3 Reactive Blue 5 除去処理におけるろ過溶液と上澄 みとの比較

除去率 $(\%)$

\begin{tabular}{|c|c|c|c|c|c|c|c|c|}
\hline & \multicolumn{2}{|c|}{$\begin{array}{c}\text { 塩焚き爺 } \\
\text { の天然 } \\
\text { にがり }\end{array}$} & \multicolumn{2}{|c|}{$\begin{array}{c}\text { 石垣島の } \\
\text { にがり }\end{array}$} & \multicolumn{2}{|c|}{$\begin{array}{c}\text { 室戸海洋 } \\
\text { 媣層水 } \\
\text { 天然にがり }\end{array}$} & \multicolumn{2}{|c|}{ 瀬讃のにがり } \\
\hline 万過 & 64 & (1.5) & 61 & (1.4) & 87 & $(0.95)$ & 98 & $(0.065)$ \\
\hline 上澄み & 77 & (1.3) & 75 & (1.3) & 94 & $(0.47)$ & 99 & $(0.074)$ \\
\hline
\end{tabular}

ついてもプロファイルを測定し，にがりをアルカリ性 にした際に生じる沈殿との比較を行った。

\section{3. 結果及び考察}

\section{1 試料前処理条件の検討}

表 3 に上澄みとそのろ過溶液の除去率を示した。 上 澄みは75～99\%の除去率であったが，ろ過溶液は61〜 98\% と除去率は低くなった。これは水酸化マグネシウ ムが沈殿する際にトラップされた染料粒子がろ過によ り力が加わることで押し出された結果， 万液中の濃度 が高くなったと考えられる。一方，イオン交換膜濃縮 にがりで処理を行った溶液は静置沈降させた上澄み表 面にカルシウム化合物が浮遊していたため, 析出沈殿 物はすべてろ過により除去することとし，条件を合わ せた。また，ろ紙への染料の吸着はほとんど確認され なかった（図 1 )

\section{2 反応染料及び食用タール系色素の沈殿除去 処理}

反応染料及び食用タール系色素を種類の異なるにが りで除去処理を行った結果を表 4 に示した。

反応染料は全体的に除去率が高かったが，Reactive Blue 5 及び Reactive Orange 14はイオン交換膜濃縮 にがりの除去率が87〜98\%に対して海水濃縮にがりの

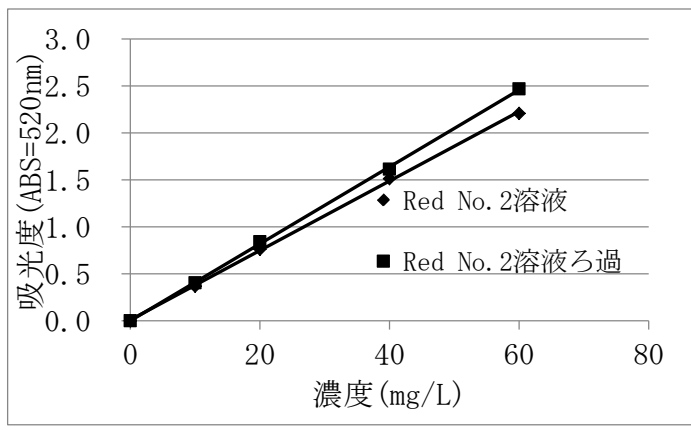

(2) Food Red No.2のろ紙吸着の検討

図 1 各染料によるろ紙吸着の検討 
表 4 にがりの種類が反応染料及び食用タール系色素の除去率に及ぼす影響

除去率 $(\%)$

\begin{tabular}{|c|c|c|c|c|c|c|}
\hline & \multirow[b]{3}{*}{ 分類 } & \multirow[b]{3}{*}{ 染料製品名 } & \multicolumn{4}{|c|}{ にがり製品名 } \\
\hline & & & \multicolumn{2}{|c|}{ 海水濃縮にがり } & \multicolumn{2}{|c|}{ イオン交換膜濃縮にがり } \\
\hline & & & $\begin{array}{l}\text { 塩焚き爺の } \\
\text { 天然にがり }\end{array}$ & $\begin{array}{c}\text { 石垣島 } \\
\text { 天然本にがり }\end{array}$ & $\begin{array}{l}\text { 瀬讃の } \\
\text { にがり }\end{array}$ & $\begin{array}{c}\text { 室戸海洋深層水 } \\
\text { 天然にがり }\end{array}$ \\
\hline \multirow{6}{*}{$\begin{array}{l}\text { 反応 } \\
\text { 染料 }\end{array}$} & \multirow{2}{*}{ アゾ } & Reactive Black 5 & $91(0.83)$ & $90(1.6)$ & $100(0.0073)$ & $99(0.45)$ \\
\hline & & Reactive Orange14 & $67(3.3)$ & $69(6.9)$ & $95(0.54)$ & $91(0.55)$ \\
\hline & \multirow{2}{*}{$\begin{array}{l}\text { アントラ } \\
\text { キノン }\end{array}$} & Reactive Blue 5 & $64(1.5)$ & $61(1.4)$ & $98(0.065)$ & $87(0.95)$ \\
\hline & & Reactive Blue 19 & $96(0.15)$ & $96(0.050)$ & $99(0.027)$ & $99(0.088)$ \\
\hline & & 反応染料平均 & 80 & 79 & 98 & 94 \\
\hline & & にがりの種類別平均 & & 79 & & 96 \\
\hline \multirow{6}{*}{$\begin{array}{c}\text { 食用 } \\
\text { タール } \\
\text { 系色素 }\end{array}$} & \multirow{2}{*}{ アゾ } & Food Red No.2 & $59(2.0)$ & $57(2.5)$ & $98(0.20)$ & $92(0.13)$ \\
\hline & & Food Red No.40 & $68(2.7)$ & $59(2.1)$ & $94(0.24)$ & $87(1.9)$ \\
\hline & \multirow{2}{*}{ キサンテン } & Food Red No.3 & $64(5.5)$ & $52(4.5)$ & $92(0.54)$ & $80(1.0)$ \\
\hline & & Food Red No.106 & $26(2.6)$ & $24(3.5)$ & $23(1.4)$ & $25(5.4)$ \\
\hline & & 食用タール系色素平均 & 54 & 48 & 77 & 71 \\
\hline & & にがりの種類別平均 & & 51 & & 74 \\
\hline
\end{tabular}

測定は $\mathrm{n}=3$ で行った。（）は標準偏差.

除去率が61〜69\%であり，にがりの種類による影響が 見られた。

食用タール系色素は着色物質やにがりの種類の違い により除去率に大きな差が生じた，Food Red No.2, Food Red No.40, Food Red No.3は比較的除去効果が 高く，海水濃縮にがりによる除去率が52〜68\%である のに対し，イオン交換膜濃縮にがりを用いた場合は80 〜98\%と高かった。一方，Food Red No.106はいずれ の場合も除去率は23〜25\%と低い值であった。にがり の種類では海水濃縮にがりの除去率が 24 68\%で平均 51\%，イオン交換膜濃縮にがりの除去率が23９8\%で 平均 $74 \%$ あ゙った。ここでも反応染料と同様ににがり の種類による影響が見られ，海水濃縮にがりよりイオ ン交換膜濃縮にがりが高い効果を示した。

\section{3 にがりの成分の違いが除去効果に及ぼす影響}

にがりによる凝集沈殿法では $\mathrm{Mg}(\mathrm{OH})_{2}$ の共沈作用 を利用しているため除去率は $\mathrm{Mg}$ 濃度に依存すると考 えられる。表2の結果から，イオン交換膜濃縮にがり は $\mathrm{Mg}$ 濃度が高く, 海水濃縮にがりは $\mathrm{Mg}$ 濃度が低い ことがわかる。そこで，Mg 濃度の影響を調査するた めに，にがりの添加量を変化させて着色水の沈殿除去 処理を行った。

代表例として，にがりの種類による除去率の差が比 較的大きかった Reactive Blue 5 と Food Red No.2を 取り上げ，図2に示した。イオン交換膜濃縮にがりで

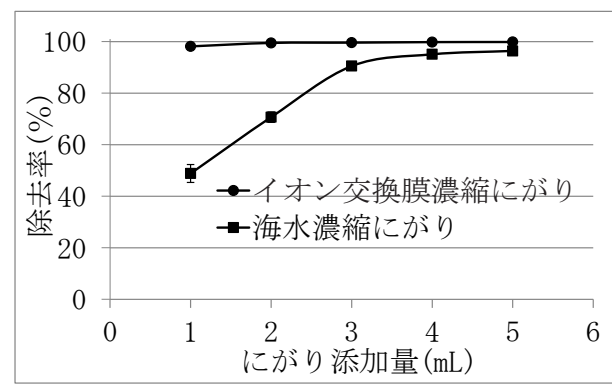

(1) Reactive Blue 5 の脱色結果

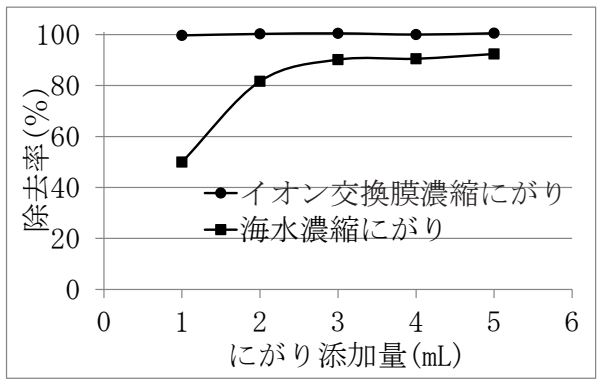

(2) Food Red No.2の脱色結果

図 2 にがり添加量の違いによる脱色結果

は Reactive Blue 5 が98〜100\%, Food Red No.2が 100\%の除去率であった。一方，海水濃縮にがりは添 加量の増加と共に除去率も上昇したが， $5 \mathrm{~mL}$ 添加で も除去率100\%に達することはなかった．表２よりイ オン交換膜濃縮にがりの $\mathrm{Mg}$ 濃度は海水濃縮にがりの 
約1.5倍程度であるため, 理論上では, 海水濃縮にが りは $2 \mathrm{~mL}$ 添加すれば除去率がほぼ100\%に達するは ずである。しかし除去率は $2 \mathrm{~mL}$ 添加で70 80\% 程度 であったことから，単に $\mathrm{Mg}$ 量のみが影響していると は言い難い結果となった。そこで海水濃縮にがりとイ オン交換膜濃縮にがりそれぞれの特徵的成分である $\mathrm{Ca}$ 及び $\mathrm{SO}_{4}$ が沈殿除去処理に与える効果を検討する こととした。

$\mathrm{Ca}$ 及び $\mathrm{SO}_{4}$ の影響を評価するため $\mathrm{MgCl}_{2}$ 量を固定 し, $\mathrm{Ca}$ 及び $\mathrm{SO}_{4}$ の濃度を変化させて Reactive Blue 5 及びFood Red No.2の沈殿除去処理を行った結果を 図 3 に示した。除去率は $\mathrm{Ca}$ 添加量の増加に伴い向上 したが, SO4添加量の影響は見られなかったことから， Caは効果があり， $\mathrm{SO}_{4}$ の妨害はないことが確認された. $\mathrm{Ca}$ は $\mathrm{Mg}$ と同様 2 価の陽イオンであり，これを含む 溶液をアルカリ性にすると，水酸化物を形成すること から，イオン交換膜濃縮にがり中の Ca はアルカリ性 にすることで $\mathrm{Ca}(\mathrm{OH})_{2}$ となり，それが $\mathrm{Mg}(\mathrm{OH})_{2}$ と同 じような働きをしていると考えられる。また， $\mathrm{Ca}(\mathrm{OH})_{2}$ はそれ自体で凝集効果があり，アルカリ添加 剤として $\mathrm{Ca}(\mathrm{OH})_{2}$ を使用すると効果が高いという報

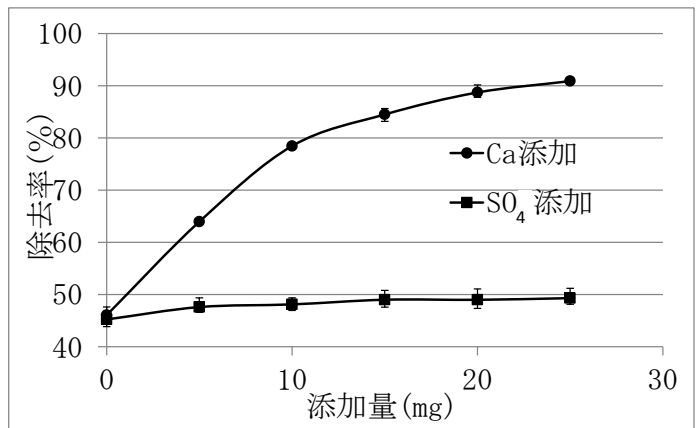

(1) Reactive Blue 5 の脱色結果

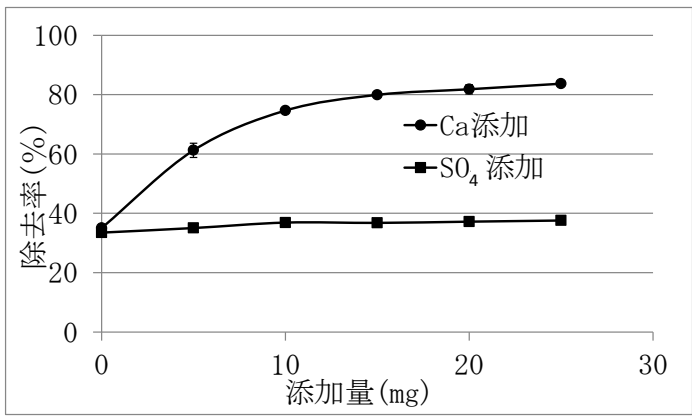

(2) Food Red No.2の脱色結果

図 3 Ca，SO添加量の違いによる脱色結果
告がある ${ }^{8)}$.

\section{4 にがりをアルカリ性にした際に生じる沈殿 の同定}

にがりをアルカリ性にした際に生じる沈殿について それぞれのにがりの沈殿物についてX線回折分析 （Rigaku 製 MiniFlex II を使用）を行った。図 4 に示 したように，検出された沈殿物のピークは本報で用い た 4 種類すべてのにがりで観察され，それらは $\mathrm{Mg}(\mathrm{OH})_{2}$ 特有のプロファイルを示したことから，沈 殿物に $\mathrm{Mg}(\mathrm{OH})_{2}$ が含有されていることが確認された. また，イオン交換膜濃縮にがりである瀬讃のにがりと 室戸海洋深層水天然にがりのピークは $\mathrm{CaCO}_{3}$ 特有の プロファイルを示したことから $\mathrm{CaCO}_{3}$ が生成したと 考えられる。このことからイオン交換膜濃縮にがり中 の $\mathrm{Ca}$ イオンは $\mathrm{pH}$ の上昇に伴い, $\mathrm{CaCO}_{3}$ となって沈 殿したことが明らかとなった。これは $\mathrm{Ca}(\mathrm{OH})_{2}$ と $\mathrm{CaCO}_{3}$ の溶解度の差によるもので, $\mathrm{Ca}(\mathrm{OH})_{2}$ が 1,850 $\mathrm{mg} / \mathrm{L}$ でるのに対して $\mathrm{CaCO}_{3}$ は $14 \mathrm{mg} / \mathrm{L} て ゙ あ り ，$ $\mathrm{CaCO}_{3}$ の溶解度は $\mathrm{Ca}(\mathrm{OH})_{2}$ の約1/130である。このた め $\mathrm{Ca}(\mathrm{OH})_{2}$ となる前に水中の炭酸イオンと反応して $\mathrm{CaCO} 3$ が析出したと思われる。さらに, $\mathrm{CaCO}_{3}$ には凝 集作用が確認されて㧍り，下水中の $\mathrm{TOC}$ が $\mathrm{CaCO}_{3}$ に よって $45 \%$ 減少したという報告がある ${ }^{9)}$. 既存の凝集 沈殿の報告とも一致するため, 本報においても $\mathrm{CaCO}_{3}$ による凝集作用と言える。

以上の結果よりイオン交換膜濃縮にがりは凝集作用 のある $\mathrm{Ca}, \mathrm{Mg}$ 高濃度に含んでいるため, 海水濃縮に がりと比較し, 除去効果が高いことが明らかとなった。

\section{4. まとめ}

4 種類の市販にがりを用い，反応染料及び食用ター ル系色素の沈殿除去処理を検討した。 反応染料は全体 的に除去率が高かったが, 食用タール系色素は色素の 種類による除去率の差が大きかった。

反応染料及び食用タール系色素の沈殿除去処理は海 水濃縮にがりと比較してイオン交換膜濃縮にがりが高 い効果を示し，有効であった。イオン交換膜濃縮にが りは $\mathrm{Mg}$ を多く含み, $\mathrm{Ca}$ も多く含まれているため, 高い効果をもたらしたと考えられる。なお，SO4は影 響しなかった。

X線回折分析の結果から，イオン交換膜濃縮にがり をアルカリ性にした際に生じる沈殿物は $\mathrm{Mg}(\mathrm{OH})_{2}$, $\mathrm{CaCO}_{3}$ であることが確認された，着色物質はこれらの 


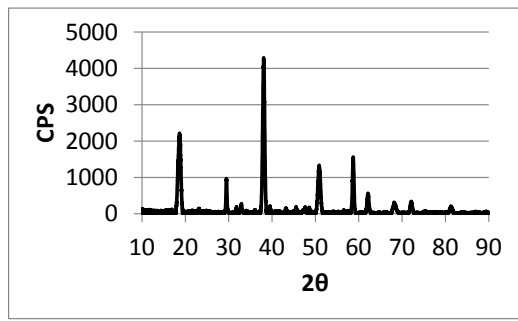

（1）瀬賛のにがり

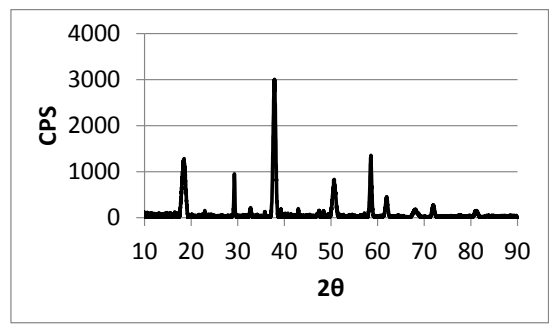

（2）室戸海洋深層水天然にがり

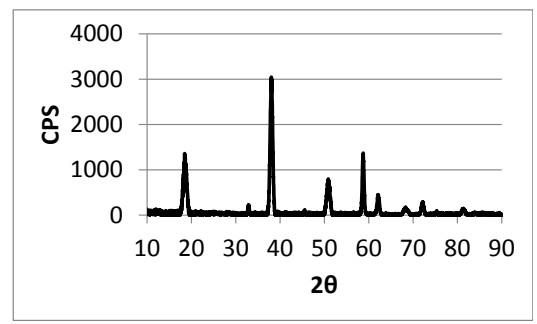

(3) 石垣島天然本にがり

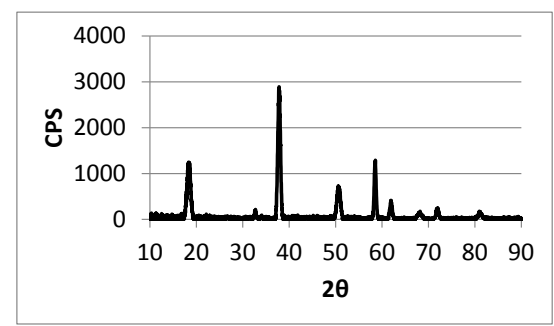

（4）塩焚き啷の天然本にがり

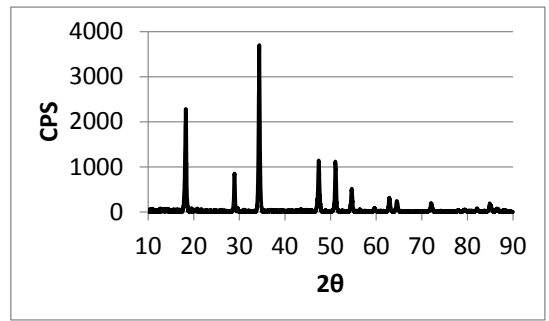

(5) $\mathrm{Ca}(\mathrm{OH})_{2}$

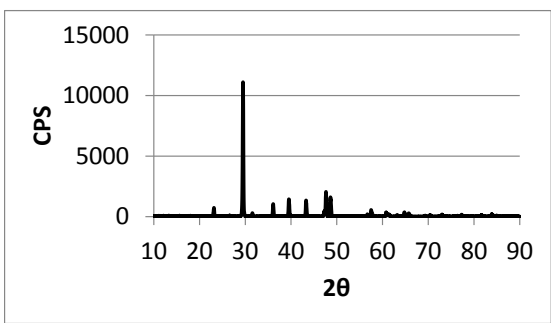

(6) $\mathrm{CaCO}_{3}$

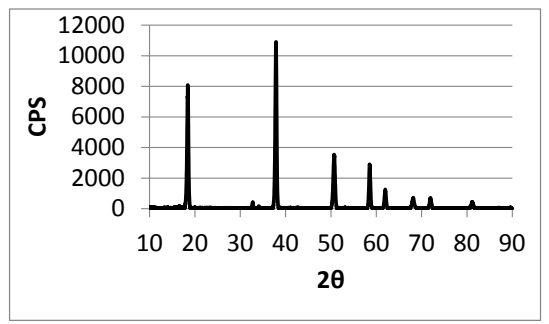

(7) $\mathrm{Mg}(\mathrm{OH})_{2}$

\section{図 4 X線回折分析の結果}

沈殿物に取り込まれ共沈し，着色物質が除去されたと 考えられる。

\section{参考文献}

1 ) 小林幸久, 佐藤直人, 石村亜矢; 染料含有着色廃水の処 理方法, 特開平6-126286.

2 ) 渡辺実; 凝集郕の特性と効果的選定 - 活用法 - 講習会厅 キスト 一, 技術情報センター, 2011.

3 ) 財塩事業センター; 海水と製塩データブック，2006.

4 ) Paul Rogers, San Jose ; Mercury News, "US: Cargill Fined by State Over Toxic Spill into Bay", CORP WATCH, 2006, (online), 〈http://www.corpwatch. org/article.php?id=13660〉, (accessed 2011-12-1）.

5 ) 橋本壽夫, 村上正祥; 塩の科学, 朝倉書店, 2003 .

6 ) Sung-bin Wang and K.Y. Chen ; Bitterns as Coagulants for Treatment of Color Effluents, Studies in Environmental Science, 23, 193-203, 1984.

7 ) (財)塩事業センター; 塩試験方法一第 3 版 - , 2007.

8 ) Gao B.Y., Yue Q.Y., Wang Y. and Zhou W.Z.; Color removal from dye containing wastewater by magnesium chloride, Journal of Environmental Management, 82, 167-172, 2007.

9 ) LEENTVAAR J., REBHUN M. ; Effect of magnesium and calcium precipitation on coagulation-flocculation with lime,Water Res, 16, (5), 655-662,1982. 